J. Clin. Chem. Clin. Biochem.

Vol. 19, 1981, pp. 301-304

\title{
Criticism of the Use of Coomassie Brilliant Blue G-250 for the Quantitative Determination of Proteins
}

\author{
By M. G. M. van Wilgenburg, E. M. A. Werkman, W. H. van Gorkom and J. B. J. Soons
}

\section{St. Antonius Hospital, Utrecht, The Netherlands}

(Received August 8, 1980)

Summary: The quantitative determination of proteins in biological fluids, using Coomassie Brilliant Blue G-250, was evaluated. Compared with the biuret method, the Coomassie Brilliant Blue G-250 method needs a much shorter time for analysis and has a greater sensitivity. The sensitivity of the dye for albumin is significantly greater than for globulins. The standard curves for the biuret method are more linear than those for the Coomassie Brilliant Blue G-250 method. The Coomassie Brilliant Blue G-250 method produces a precipitate, which sticks to the walls of the cuvet and results in an intolerable carry-over. Therefore, the use of the Coomassie Brilliant Blue G-250 method for the quantitative determination of proteins in urine and serum is not recommended.

\section{Kritik an der Verwendung von Coomassie Brilliant Blau G-250 zur quantitativen Bestimmung von Proteinen}

Zusammenfassung: Die quantitative Bestimmung von Proteinen in biologischen Flüssigkeiten mit Coomassie Brilliant Blau G-250 wurde kritisch untersucht. Diese Methode, verglichen mit der Biuret-Methode, erfordert wesentlich weniger Analysenzeit und besitzt eine größere Empfindlichkeit, die jedoch für Albumin signifikant höher ist als für Globuline.

Die Standardkurven für die Biuret-Methode sind linearer als die für die Coomassie Brilliant Blau G-250-Methode. Die Coomassie Brilliant Blau G-250-Methode bildet einen Niederschlag, der die Küvettenwand bedeckt und zu einer untragbaren Verschleppung führt. Die Verwendung von Coomassie Brilliant Blau G-250 zur quantitativen Bestimmung von Proteinen in Harn und Serum wird deshalb nicht empfohlen.

\section{Introduction}

For the determination of proteins in urine, serum, and cerebrospinal fluid (CSF), the biuret method (1) is most frequently used. This method, however, is rather laborious and time consuming. In 1976, Bradford (2) introduced Coomassie Brilliant Blue G-250 as a dye for the detection of proteins in diluted solutions. Binding of the dye to the protein results in a shift in wavelength of the maximum absorbance from $465 \mathrm{~nm}$ to $595 \mathrm{~nm}$. According to Sedmak (3) the dye binds to the $\mathrm{NH}_{3}^{+}$groups of the protein. The use of Coomassie Brilliant Blue G-250 in the determination of proteins in urine and CSF was suggested by McIntosh (4) and has been evaluated especially for CSF by Johnson (5) and Schleicher (6). Various authors $(7,8)$ have already reported significant differences in the sensitivities of Coomassie Brilliant Blue G-250 for various proteins. Pierce et al. (7) found great differences in the sensitivities for bovine serum albumin, cytochrome $c$, trypsin, chymotrypsin, and pepsinogen. Similar differences were found by van
Kley (8) for bovine serum albumin, cytochrome c, lysozyme, and ribonuclease. Both authors, however, failed to report the quantitation of these differences. In order to evaluate the suitability of the Coomassie Brilliant Blue G-250 method in the hospital laboratory, it is important to investigate possible differences in the sensitivity of the dye for human serum albumin, and $\alpha-, \beta$, and $\gamma$-globulins (human Cohn fractions 5, 4, 3, and 2).

\section{Materials and Methods}

Materials

Reagents were prepared as follows:

Stock solution

$3.00 \mathrm{~g}$ Coomassie Brilliant Blue G-250 (Serva, Germany, colcur index 42655$)$ were added to $400.0 \mathrm{ml}$ ethanol $(960 \mathrm{ml} / \mathrm{l})$. The mixture was stirred for two days on a magnetic stirrer, filtered by suction through a glass filter (G1), and ajusted to $500.0 \mathrm{ml}$ with ethanol $(960 \mathrm{ml} / 1)$. 
This stock solution is stable for three months at room temperature.

\section{Working solution}

$50.0 \mathrm{ml}$ stock solution was added to $100.0 \mathrm{ml}$ phosphoric acid $(850 \mathrm{~g} / \mathrm{l})$ after which the solution was made up to $1000.0 \mathrm{ml}$ with distilled water. This working solution is stable for 14 days at room temperature.

\section{Protein solutions}

The various protein solutions were prepared as follows: $0.5 \mathrm{~g} \alpha$, $\beta$-, and $\gamma$-globulin respectively were added to $50.0 \mathrm{ml} 0.1 \mathrm{~mol} / 1$ $\mathrm{NaOH}$. The $\alpha$ - and $\beta$-globulins (Cohn fractions 4 and 3) were dried material obtained from Koch Light Labs Ltd. England. The $\gamma$-globulin (Cohn fraction 2) was obtained as dry material from Sigma Chemical Company, USA. The solutions were mixed for one day on a magnetic stirrer and then centrifuged for 20 minutes at $1000 \mathrm{~g}$. Approximately $50 \mathrm{ml} 0.1 \mathrm{~mol} / 1 \mathrm{HCl}$ was carefully added to the supernatants until the $\mathrm{pH}$ became 8 . The solutions were then centrifuged again for 20 minutes at $1000 \mathrm{~g}$. A Kjeldahl protein determination was performed on the final supernatants, which were used as protein stock solutions. The bovine and human serum albumin stock solutions of $5 \mathrm{~g} / \mathrm{l}$ were prepared by diluting the concentrated, commercially available solutions with $9 \mathrm{~g} / 1 \mathrm{NaCl}$. The bovine serum albumin $(96.2 \mathrm{~g} / \mathrm{l})$ was obtained from Poviet BV, Amsterdam, and the human serum albumin $(200 \mathrm{~g} / \mathrm{l})$ was obtained from Red Cross Labs, Amsterdam. A Kjeldahl protein determination of the bovine serum albumin solution $(5 \mathrm{~g} / \mathrm{l})$ was also performed. The purity of the proteins in the various solutions was checked as follows: After concentrating the stock solutions $\mathbf{3 0}$ fold via a membrane filter (Sartorius GmbH, Germany, type SM 13202), cellulose acetate electrophoresis was carried out at pH 8.8, followed by staining with Ponceau S. After scanning with a densitometer (Clifford densicomp, modell 445) it was found that:

a) 0.70 of the $\alpha$-globulin had $\alpha$-mobility and $0.30 \beta$-mobility. b) 0.75 of the $\beta$-globulin had $\beta$-mobility and $0.25 \gamma$-mobility.

c) 0.95 of the $\gamma$-globulin had $\gamma$-mobility and $0.05 \beta$-mobility.

d) 0.99 of the bovine and human serum albumin had albumin mobility.

The pooled serum was prepared by mixing the sera obtained from 5 normal persons.

\section{Procedure}

The dye determinations were carried out by adding $0.050 \mathrm{ml}$ sample to $5.0 \mathrm{ml}$ working solution. After mixing on a rotation mixer the absorbance was measured two minutes later in a photometer (Vitatron, type UC 200) at a wavelength of 560 $\mathrm{nm}$. The working solution was used as a blank. The biuret method was carried out according to Henry (1). A $2.0 \mathrm{ml}$ sample was used to an end volume of $5.5 \mathrm{ml}$. In the Coomassie Brilliant Blue G-250 and biuret method, a reference serum (Seronorm, Nyegaard, Oslo) was used as a standard. Its total proteir. content was $67 \mathrm{~g} / 1$ and it had an albumin-globulin ratio of 0.63 . Before use, it was diluted $1: 50$ with $9 \mathrm{~g} / 1 \mathrm{NaCl}$ The protein determinations according to Kjeldahl (performed by CIVO, Zeist) were carried out using a calculation factor of 6.25 , which is the common average for human proteins. This method was used as a reference method.

\section{Results and Discussion}

Table 1 shows the protein content of the various protein stock solutions as determined by the three methods described.

Tab. 1. Protein concentrations of the four stock solutions, determined by the Kjeldahl, biuret and dye method.

\begin{tabular}{llll}
\hline & $\begin{array}{l}\text { Kjeldahl } \\
(\mathrm{g} / \mathrm{l})\end{array}$ & $\begin{array}{l}\text { Biuret } \\
(\mathrm{g} / \mathrm{l})\end{array}$ & $\begin{array}{l}\text { Dye method } \\
(\mathrm{g} / \mathrm{l})\end{array}$ \\
\hline $\begin{array}{l}\text { Bovine serum } \\
\text { albumin }\end{array}$ & 5.1 & 4.9 & 6.0 \\
$\alpha$-Globulins & 2.3 & 2.3 & 2.0 \\
$\beta$-Globulins & 3.9 & 4.3 & 3.5 \\
$\gamma$-Globulins & 4.5 & 4.4 & 3.8 \\
\hline
\end{tabular}

From table 1, it is obvious that the protein concentrations, as determined by the Coomassie Brilliant Blue G:250 method, do not correlate well with those determined by the Kjeldahl and biuret method. To find a possible explanation for this phenomenon, the following experiments were carried out. Serial dilutions, ranging from undiluted to $1: 10$ were made from the bovine serum albumin, $\alpha$-globulin, $\beta$-globulin, and $\gamma$-globulin stock solutions with $9 \mathrm{~g} / \mathrm{l} \mathrm{NaCl}$ ( 10 solutions per series). The pooled serum was diluted with $9 \mathrm{~g} / \mathrm{l} \mathrm{NaCl}$ in order to obtain a protein concentration of $1.0 \mathrm{~g} / \mathrm{l}$. As we encountered difficulties in precipitating the proteins in the biuret method (especially $\alpha$ and $\beta$-globulins), all solutions of the four serial dilutions were diluted 1:2 once more, with the pooled serum solution of $1.0 \mathrm{~g} / \mathrm{l}$. Finally, a serial dilution was made from the pooled serum with $9 \mathrm{~g} / 1 \mathrm{NaCl}$ to give a concentration range of $0.5-4.0 \mathrm{~g} / \mathrm{l}$. The five serial dilutions were measured using the biuret and Coomassie Brilliant Blue G-250 method.

The results of the computation of the linear regression lines, $\mathrm{ij}=\mathrm{mx}+\mathrm{b}$, are expressed in table 2 .

Tab. 2. Results of the computation of the linear regression lines, $\mathrm{ij}=m \mathrm{~m}+\mathrm{b}$. In the biuret method all measured points have been used; in the dye method only those points up to a concentration of $1.5 \mathrm{~g} / \mathrm{l}$.

$\mathrm{ij}=$ absorbance in units $\mathrm{x} 10^{3}$.

$\mathrm{x}=$ protein concentration in $\mathrm{g} / \mathrm{l}$

$r=$ correlation coefficient.

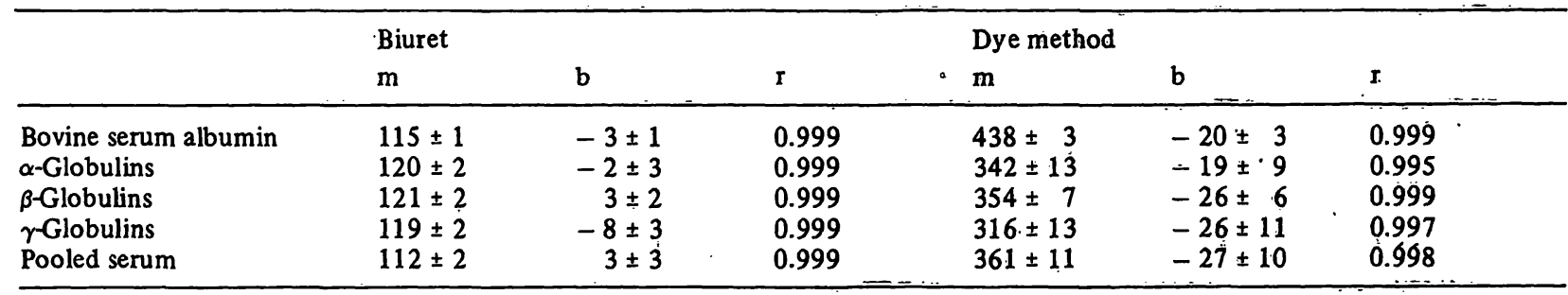


If the sensitivity of the various methods is defined as the absorbance per unit protein concentration ( $m$ in table 2 ), it appears from table 2, that the biuret method shows about the same sensitivity for the various protein fractions, whilst the Coomassie Brilliant Blue G-250 method shows a much greater sensitivity for bovine serum albumin than for the globulins. The differences in sensitivities amongst the various globulins in the Coomassie Brilliant Blue G-250 method are small. The dye sensitivity for bovine serum albumin is about 1.4 times that for $\gamma$ globulin. From the results, it also appeared that the measured points per series in the biuret method could far better be described by a straight line than those in the Coomassie Brilliant Blue G-250 method. On close inspection, it could be seen that the measured Coomassie Brilliant Blue G-250 points actually showed a bend with every serial dilution, even in the concentration range $0.025-0.50 \mathrm{~g} / \mathrm{l}$. Consequently, all measured points in the biuret method could be used for the computation of the various linear regression line parameters in table 2 , while in the dye method, the use of the measured points up to a protein concentration of $1.5 \mathrm{~g} / \mathrm{l}$ was justified, as is indicated by the correlation coefficients in table 2 . This was found in every serial dilution. As an example, the biuret and Coomassie Brilliant Blue G-250 curves for bovine serum albumin are plotted in figure 1 and figure 2.

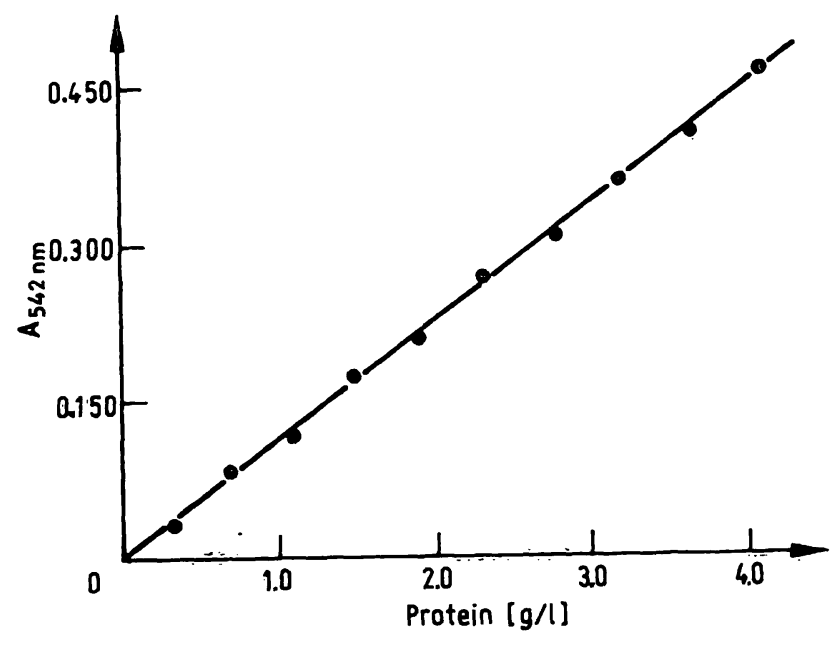

Fig. 1. Serial dilution of the bovine serum albumin stock solution, measured by the biuret method.

Thus, the protein concentrations can be measured in undiluted samples by the biuret method to a much higher level than by the dye method. The biuret method could not be investigated in the low level range, because the absorbances became too low to be measured accurately. From the results of the protein determinations in the serial dilutions of the bovine and human serum albumin stock solutions in $9 \mathrm{~g} / \mathrm{l} \mathrm{NaCl}$, it appeared that the sensitivities for bovine and human serum albumin, using the dye method, did not differ significantly. (Student test $\mathrm{p}>0.05$ ).

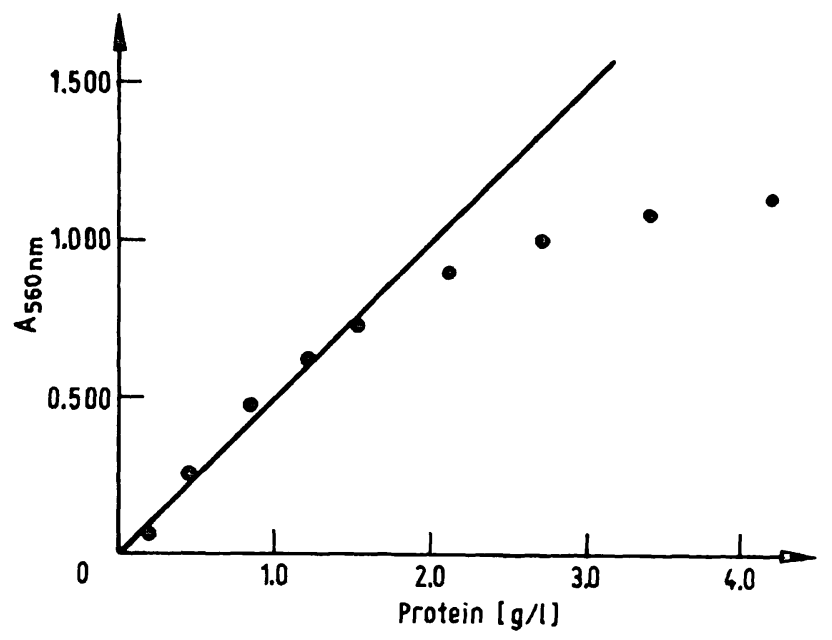

Fig. 2. Serial dilution of the bovine serum albumin stock solution, measured by the dye method.

When the sensitivities for the bovine serum albumin in the biuret and dye method are corrected for the sample dilutions, it can be seen that the dye sensitivity is 140 times greater than the biuret sensitivity.

The results of these experiments show that it is impossible to measure protein concentrations accurately if the solution to be investigated has an albumin/globulin ratio that differs too much from the albumin/globulin ratio in the reference serum used. In urines, especially, these ratios can differ considerably. For the protein determinations in CSF, one might expect less inaccuracies since the relative protein composition of CSF if often closer to that of a normal serum and of the reference serum used.

It is obvious that albumin-globulin mixtures, like urine and serum cannot be measured accurately by the dye method using a bovine serum albumin standard.

The foregoing is an explanation of the deviation of the Coomassie Brilliant Blue G-250 figures in table 1, where the value is too high for bovine serum albumin, and too low for the globulins.

Another disadvantage of the dye method is the formation of a blue precipitate (protein-dye complex) that sticks to the walls of the measuring cuvet (glass or polystyrene). The result is an unacceptable carry-over. As a consequence of this carry-over, a serial determination can definitely not be carried out starting at the highest protein concentration. This is expressed in figure 3 for bovine serum albumin. Therefore, all our measurements were performed starting at the lowest protein concentration.

The mentioned objections do not hold for the biuret method. Consequently, one has to make a choice between the fast and sensitive, but inaccurate dye method, and the slower, but more accurate biuret method. The lack of sensitivity of the biuret method in the low range 


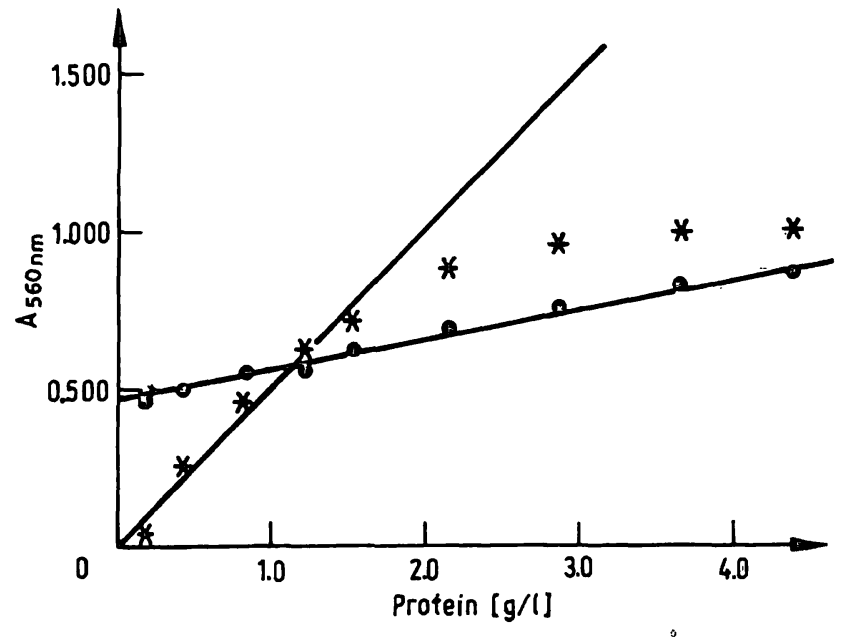

\section{References}

1. Henry, R. J. (1974), Clinical Chemistry: Principles and Technique, Harper and Row, Hagerstown, Maryland, 411-413.

2. Bradford, M. M. (1976), Anal. Biochem. 72, 248-254.

3. Sedmak, J. J. \& Grossberg, S. E. (1977), Anal. Biochem. 79, 544-552.

4. McIntosh, J. C. (1977), Clin. Chem. 23, 1939-1940.

5. Johnson, J. A. \& Lott, J. A. (1978), Clin. Chem. 24, $1931-1933$. is clinically irrelevant, and in the range $0.50-4.0 \mathrm{~g} / 1$ sensitivity is sufficient.

Therefore, in spite of the continuous quest for faster and more sensitive methods, the Coomassie Brilliant Blue G-250 method is not the method of choice for accurate protein determinations in urine or serum.

Fig. 3. Serial dilution of the bovine serum albumin stock solution, measured by the dye method.

- $\bullet$ series, measured from the high to the low protein concentration.

*** series, measured from the low to the high protein concentration.
6. Schleicher, E. \& Wieland, O. H. (1978), J. Clin. Chem. Clin. Biochem. 16, 533-534.

7. Pierce, J. \& Suelter, C. H. (1977), Anal. Biochem. 81, 478-480.

8. van Kley, H. \& Hale, S. M. (1977), Anal. Biochem. 81 , $485-487$.
Drs. M. G. M. van Wilgenburg St. Clara Hospital Olympiaweg 350

NL-3078 HT Rotterdam 